\title{
Problems of improving the means of legal regulation agro-industrial complex in the context of ensuring food security of the Russian Federation
}

\author{
Nikolay Saraev ${ }^{1,2, *}$, Vasily Vlasov², Galina Vlasova ${ }^{2}$, and Svetlana Denisenko² \\ ${ }^{1}$ Don State Technical University, Gagarin sq. 1, 344003, Rostov-on-Don, Russia \\ ${ }^{2}$ Russian State University of Justice (Rostov Branch), Lenin ave, 66, 344038 Rostov-on-Don, Russia
}

\begin{abstract}
Purpose: The purpose of current work is to study the problems of legal regulation of issues related to efficient and rational land use, the search for sources of capital accumulation to ensure sustainable agricultural production. Design/methodology/approach: The methodological basis of the research was formed by general scientific and private scientific methods. Findings: One of the main tasks of any state is to ensure food security, since it is an integral part of the country's national security. In Russia, this aspect of security remains an important area of government policy and lawmaking. At the same time, the depressive state of the industry indicates the low efficiency of the means of legal regulation of the agro-industrial complex. Originality/value: The factor of state structural policy in agriculture determines the main directions of development and institutional parameters of agricultural producers through legislative and financial policies. At the same time, law-making policy is an instrument for carrying out structural policy in agriculture, both at the federal and regional levels, since the state adopts laws that determine the further existence and development of various categories of farms.
\end{abstract}

\section{Introduction}

Over the past seven years, the activities of subjects of financial and economic relations have been carried out under the pressure of the regime of external economic sanctions. The functioning of the sectors of the economy in the new conditions naturally necessitated an indepth analysis of the state of sustainability of the system of the agro-industrial sector, taking into account internal contradictions, including those related to the problems of legal regulation. The forced response to the predicted negative trends revealed the factors of food security in Russia in the areas of the use of land resources, animal husbandry, and processing of agricultural products.

So, in April 2021, an organized criminal group was established in the Rostov region that illegally seized municipal land worth over 426 million rubles. Trade facilities, brothels for organizing prostitution, gambling clubs were located on land plots, bypassing tax legislation, dozens

\footnotetext{
*Corresponding author: snv_571978@mail.ru
} 
of buildings were illegally erected and connected to communications, in which illegal migrants lived, and wastes were stored.

The Russian business ombudsman B. Titov in 2021 called the actions of the security forces in the case of the Pokrovsky concern on the facts of illegal seizure of farmland of farmers in the Southern Federal District of the Russian Federation as a "powerful blow to raiding".

The risks of economic activity become acute due to the loss of control and control over the veterinary and sanitary state of the territories, as part of the fight against dangerous animal diseases. Back in 2010, experts noted that the dynamics of the unfavorable situation with regard to African swine fever in Russia is associated with the lack of a unified system for the prevention, detection and elimination of dangerous animal diseases, improper and negligent performance by workers of the municipal and regional levels of social management of their official duties, formal quarantine behavior. restrictive measures, violations of veterinary legislation [1]. The threat to epidemiological safety is created by violations of veterinary legislation in terms of utilization of biological waste associated with the absence of biothermal pits. According to the Veterinary Directorate of the Rostov Region, there are 75 cattle burial grounds in the region, of which 27 are in unsatisfactory condition, and 31 are ownerless, which in the future may have a negative impact on the development of animal husbandry in the federal district. So, in February 2021, specialists from the Tatar Interregional Veterinary Laboratory discovered genetic material (DNA) of the African swine fever pathogen in sausages from the Rostov region.

Today it is premature to talk about the economic growth of the agricultural sector; moreover, there are a number of systemic problems, the solution to which has not been found: the issues of low investment attractiveness of the agricultural sector and the attraction of human capital. The problems of ensuring the progressive economic development of the agro-industrial complex remain, the competitiveness of domestic agricultural products remains insufficient.

The transformation of the economic system of the agrarian complex and the formation of appropriate organizational and economic mechanisms necessitate the development of a new legal paradigm for the legal regulation of relations in the field of agricultural production.

\section{Research materials and methods}

In the course of the application of comparative legal, statistical and sociological methods, the method of expert assessments, the study of public opinion on the perception and reproduction of normative attitudes in modern conditions was carried out, the synthesis of data on the processes of lawmaking and law enforcement in the Russian Federation.

\section{Results}

In modern conditions, almost no country can develop without economically strong agriculture, due to which the population is mainly supplied with domestic food. In this respect, Russia is no exception, as it has a huge agrarian potential. However, for many years it remains the world's largest net importer of food products and agricultural raw materials, mainly due to the inability of the agrarian sector of the economy and especially its basic industry - agriculture - to ensure the country's food independence.

Without the development of a new national agrarian policy and without giving it an official state status, the scattered, inconsistent and uncoordinated among themselves numerous developed various federal and regional concepts, programs for the socio-economic 
development of the agrarian sector of the economy, legislatively not supported by the necessary state funding, have a relatively low probability of practical implementation markets [2].

Agrarian policy should take into account and support by economic measures the existing division of production and labor between small forms of management and large agricultural organizations. It should take into account the significant changes that have occurred in the structure of agriculture in recent years, and correctly determine the further development of small forms of farming in the near and long term [3].

Sustainable development of rural areas is understood as the stable development of agriculture, ensuring: 1) fulfillment of his national economic functions (production of food, agricultural raw materials, other goods and services, as well as public goods, provision of recreational services, preservation of rural lifestyle and rural culture, social control over the territory, preservation of historically developed landscapes; 2) expanded reproduction of the population, an increase in the level and improvement of the quality of its life; 3) maintaining ecological balance in the biosphere.

The food problem manifested itself most acutely when Russia introduced certain special economic measures in order to ensure the country's security, when about one fifth of its imports of food products and agricultural raw materials fell under foreign sanctions.

The main goal of the transformation of agricultural enterprises is their quick adaptation to market relations, ensuring the efficiency and reliability of the enterprise development. The Russian government is taking measures to substitute imports, to saturate the domestic market with domestic products. At the same time, the main goal of import substitution should be not only an increase in production volumes, but also an increase in the competitiveness of domestic agricultural products, raw materials and food, both in the domestic and foreign markets [4].

In the course of the study, it was found that the recognition of the systematic nature of violations in a particular area negatively affects the overall assessment of the work of state bodies. So, regularly the bodies of Roskachestvo, created by the Government of Russia in 2015, publish about massive flagrant violations revealed as a result of inspections of meat, dairy and other products, thereby stating the inability of the regulatory authorities to correct the situation. This practice leads to the spread of stereotypes that it is permissible to violate the legal requirements of not only bylaws, but also legislation without serious consequences.

When asked whether doing business in Russia can be considered safe, more than $74 \%$ of those surveyed answered negatively. At the same time, about $94 \%$ of entrepreneurs consider doing business in Russia unsafe. In such conditions, citizens form a general idea of the law enforcement system, guided by the criminal-psychological portrait of corrupt officials of the highest echelons of power. So, according to the data of the survey, $72 \%$ of the respondents noted the uselessness of contacting law enforcement agencies in the event of a criminal encroachment and their readiness to independently take action to restore justice. However, the boundaries of arbitrariness are associated with the escalation of unlawful behavior, this is especially evident against the background of the spread of criminal practices of resolving economic disputes, domestic conflicts, clarifying relations with political opponents. It is argued that the dominance of informal relations over formal regulators is the main feature that distinguishes Russia from European countries [5].

World experience shows that a country is food-independent if the share of imports to domestic consumption ranges from 20-25\%. In Russia, according to statistical data, it is $30 \%$ and more. In this regard, the primary tool for reducing import dependence on food should be rational, economically justified state financial support [6].

Imported certain types of food products and agricultural raw materials are significantly superior in quality and much cheaper than domestic ones, and are also required in minimal volumes to increase competition in the domestic agri-food market. With all types of 
productive resources, the country does not have the full amount of food to meet domestic needs, which cannot be replaced by any one resource.

The threshold values of the food security doctrine of the Russian Federation were exceeded only for grain, vegetable oil, sugar and potatoes (Table 1).

Table 1. The share of agricultural products, raw materials and food of domestic production in the total volume of resources in the Russian Federation, \%.

\begin{tabular}{|l|c|c|c|c|c|c|c|}
\hline \multirow{2}{*}{$\begin{array}{c}\text { Types of } \\
\text { agricultural } \\
\text { products. raw } \\
\text { materials and food }\end{array}$} & $\mathbf{2 0 1 0}$ & $\mathbf{2 0 1 1}$ & $\mathbf{2 0 1 2}$ & $\mathbf{2 0 1 3}$ & $\mathbf{2 0 1 4}$ & $\begin{array}{c}\text { Target } \\
\text { indicator of the } \\
\text { State Program } \\
\text { in 2014 }\end{array}$ & $\begin{array}{c}\text { Doctrine } \\
\text { thresholds } \\
\text { (not less) }\end{array}$ \\
\hline Grain & 99.4 & 99.3 & 98.8 & 98.4 & 98.9 & 99.5 & 95.0 \\
\hline Vegetable oil & 76.6 & 78.0 & 83.6 & 81.3 & 84.4 & 83.0 & 80.0 \\
\hline Sugar & 57.6 & 62.4 & 77.9 & 84.6 & 82.0 & 79.3 & 80.0 \\
\hline Potatoes & 96.3 & 95.3 & 96.8 & 97.5 & 97.4 & 98.2 & 95.0 \\
\hline Milk. dairy products & 79.7 & 79.9 & 78.9 & 76.5 & 78.3 & 81.0 & 90.0 \\
\hline $\begin{array}{l}\text { Meat and meat } \\
\text { products }\end{array}$ & 71.4 & 73.4 & 74.8 & 77.5 & 81.5 & 78.9 & 85.0 \\
\hline
\end{tabular}

The country's high and unjustified import dependence on certain types of food significantly reduces economic security, significantly infringes on its national interests, since it has to pay for imports of food products with non-renewable natural resources and weakening its role in the world economy, trade and politics. For many years, the focus on large-scale imports as the main means of solving the food problem in the country damages its economy and, above all, the basic sub-sectors of agriculture, dooming them to destruction and degradation.

Anti-Russian sanctions have increased the economic risks in the agricultural sector of the economy and have caused additional difficulties in the reliable provision of the population with domestic food, which should include:

- an increase in the risk of a decrease in state support, first of all, for agriculture and the implementation of new investment projects due to the impossibility of attracting the necessary investments in the industry due to a significant reduction and at the same time a rise in the cost of loans, which is a significant brake in ensuring the normal reproduction process in the industry;

- high dependence of certain subsectors of agriculture, food and processing industries on import supplies of seeds, genetic material, new technologies, technological equipment, plant protection chemicals, feed additives, veterinary drugs and the inability to establish their production in the country in a relatively short time, which in the conditions devaluation of the ruble and high inflation requires more expensive investments for accelerated import substitution;

- low rates of structural and technological modernization of agriculture, renewal of its basic production assets and reproduction of natural and economic potential in the conditions of maintaining an unfavorable socio-economic situation for the functioning of the industry, significant depletion of the demographic potential of the village and the inability to stop this negative process in a short time, especially in many regions the European part of the country and the Far East with an alarming rate of decline in the rural population.

\section{Output}

The emergence of conditions for distribution is associated with the introduction of a two-tier structure of veterinary control: federal and regional, with overlapping functions, as well as the introduction of payment for veterinary services, a reduction in the number of veterinary 
workers at the production and territorial levels of veterinary authorities. Thus, the formed system for the prevention and elimination of epizootics leads to a dilution of responsibility for authority, a decrease in the level of efficiency in taking measures in the event of a threat of especially dangerous epizootic situations, an increase in the priority level of the provision of paid veterinary services over supervisory and control functions, the creation of prerequisites for concealing the facts of the emergence of foci of infectious animal diseases and ignoring the instructions and proposals of veterinary authorities on the part of economic entities and executive authorities of regions and municipalities.

The transformation of the system of legal regulation of public relations in the field of the agro-industrial complex should be aimed at solving the following tasks:

- restoration of production capacities in agriculture;

- solving the problem of land tenure and land use, based on the real possibilities and needs of agriculture, as well as in the interests of rural residents;

- recognition and implementation of the principles of social and economic diversity of agriculture, the main of which is the creation of equal economic conditions for the functioning and development of agricultural producers, regardless of the organizational and legal forms of management and ownership;

- availability and targeting of state support for agricultural producers;

- rural development and narrowing the gap in the level and quality of life of the urban and rural population.

The new domestic agricultural policy should orient the agrarian sector of the economy to the maximum extent to achieve food independence of the country by turning, first of all, agriculture into a sector of accelerated development of rural areas, eliminating the negative foreign trade balance for food products and agricultural raw materials. Therefore, it is not necessary to adjust the methods and mechanisms of the current state agrarian policy, but to develop a qualitatively different model of it, the strategic direction of which is, first of all, the consistent intensification of agriculture and the radical improvement of life in the countryside, capable of ensuring a reliable supply of the country's population with domestic food, to carry out in rational the size of the accelerated import substitution.

\section{References}

1. A.N. Tarasov, The role of national public and global institutions for the development of the agro-industrial complex in Russia and abroad: materials of the international scientific and practical conference (Rostov-on-Don, 2015)

2. A.I. Altukhov, Trends and patterns of development of the agro-industrial complex of Russia: national and international aspects: materials of the international scientific and practical conference (Rostov-on-Don, 2017)

3. V.V. Kuznetsov, The role of national public and global institutions for the development of the agro-industrial complex in Russia and abroad: materials of the international scientific and practical conference (Rostov-on-Don, 2015)

4. S. Kuzina, I. Sagiryan, G. Fomin, Trends in the Development of Psycho-Pedagogical Education in the Conditions of Transitional Society ICTDPP-2019 (2019)

5. A.V. Tikhonova, State regulation of the main factors of production in the agro-industrial complex: monograph (INFRA-M, M., 2018)

6. M. Bellouma, Global Journal of Management and Business Research: B Economics and Commerce 14(3) (2014)

7. Eneida Thomaj, European Scientific Journal 10(31), 247-257 (2014)

8. G.M. Llanto, Asian Journal of Agriculture and Development 4(2), 23-40 (2014) 
9. R. Meyer, Finance for Food, 91-92 (2014)

10. A. Zheiliaskov, S. Berjan, O. Fotina et al., Partnership of government, business and higher education institutions in fostering economic development: proceedings of the $3^{\text {rd }}$ international conference of the faculty of Economics Brcko-Brcko (2016)

11. A. Zheliaskov, H. El Bilali, S. Jankovic et al., 8th International Conference on Environmental and Rural Development (Nonthaburi, Thailand, 2017)

12. F.N. Finley, Future Earth-Advancing Civic Understanding of the Anthropocene Hoboken (John Wiley \& Sons Inc., NJ, 2014)

13. V.V. Eremyan, E.T. Eshinimaeva-Shagdarova, Journal of Fundamental and Applied Sciences 10 (2018)

14. P. Leyland, G. Anthony, Textbook on Administrative Law (Oxford Universitu Press, 2013)

15. International Aspeckts of Brexit: Britains Overseas Territories u Gibraltar,Journal of Fundamental and Applied Sciences 10 (2018)

16. D.J. Arenas, A. Thomas, J. Wang et al., Journal of General Internal Medicine (2019)

17. J. Bremer, Foreign affairs May/June, 40-55 (2009)

18. S. Msangi, M. Rosengrant, World agriculture in a dynamically - changing environment (Wash., 2007)

19. P.E. Hildebrand, Poverty, growth, and ineguality over next 50 year (London, 2002) 